\title{
5. Communications, contacts, ethics and the mysterious slow death of the contemporary police reporter
}

\section{ABSIRACII}

This article, based on interviews, research and the author's personal experience in the media for more than 30 years as a police/crime reporter, former Head of Public Affairs for the Australian Federal Police and journalism lecturer, will examine the unique challenges and role of reporting police/emergency/crime journalism - how it can work and how it can break down. It will particularly examine the mostly unequal relationships between journalists and official sources where the various emergency services, notably the police, trade on releasing selected information and avoid releasing information if it is unfavourable or inconvenient. It will cover the important aspects of sources, both official and unofficial, on and off-the-record agreements, anonymous sources, ethically and unethically obtained material and the all important overriding considerations of the law including criminal processes, defamation, sub judice, jurisdictional restrictions, pre-trial publicity and trial by the media. These stories can challenge even the most experienced journalist placing demands on almost all of their skills. If done properly, journalists can fulfil the paramount responsibility of informing the public on critical matters and maintaining the media's role of being an effective Fourth Estate.

\section{PHILIP CASTLE}

Queensland University of Technology

Crime is the melting pot of everything in our society. It's traumatic and heart-breaking. Children are always difficult. The stories are enduring. You must understand clearly what is on and off-the-record.-The Courier Mail's police crime reporter, Paula Doneman, November 2006. 
There are very few effective police/crime reporters. They are a threatened species and, of all the rounds, it is the most difficult. There are some absolutes; to be accurate, immediate, know the background, don't burn your sources and not become too cosy, particularly with the police and union. - Channel Nine police reporter, Steve Marshall, Queensland, November 2006.

There are not many people who can do the police/crime round well and those that can, have largely moved on. Newsrooms need to give it greater attention and they'd probably get a better story and better results. - Head of Queensland Police media and a former print reporter, Leon Bedington, November 2006.

\section{Introduction}

7 HE best journalists, we are often told, are those driven by idealism (Dunlevy, 1985). Survival is also the key. There will always be

reporters who are driven by the Clark Kent-style reporting of pursuing truth and justice but their superman skills are often underrated or now overlooked in the modern news' context. They need more than ever to guard and exercise the role of the Fourth Estate.

The contemporary police/crime reporter is rapidly becoming a rarity and has nearly always fought an unequal battle with the police services, massaging their difficult and sensitive sources and now, more than ever, their own news rooms. In addition few media groups worry much about having specialist police reporters and rely more on their general reporters or whoever happens to be available. This simply isn't good enough and this article argues to do this job well requires all the tools in the kit-bag of a skilled journalist professional. These skills include:

1. An incredibly highly developed sense of news values and not only the primary story, but for the deeper perhaps more important story.

2. A refined sense of accuracy and the need to check material.

3. A keen sense of the importance of sources and to observe their confidentiality and protection.

4. Listening and interviewing skills.

5. Knowing what's on and off the record.

6. Avoiding the trap of becoming a 'captive' journalist.

7. Being challenged more than almost any other round on ethical dilemmas. 
8. Being alert to other agendas.

9. Being prepared to mix and listen to almost any person including the most disliked, eg criminals, corrupt politicians, paedophiles.

10. Being engaged with people who are highly stressed and traumatised by the worst events in their lives.

11. Avoiding causing any further harm.

12. Being alert to your own safety.

13. Disruption of shift work while nearly always 'on duty' 24 hours a day.

14. Allowing contacts to tip you off at any time.

15. Coping with your own personal trauma and the very real possibility of developing post traumatic stress disorder.

16. Often the police/crime reporter will feel isolated undertaking their stories and in many instances there is an apparent lack of support and or understanding by the news room directors about the difficulties and nature of gathering effective police/crime stories.

The most common concerns expressed by many police reporters in this field are the unreasonable demands placed on them to undertake the 'infamous' death-knocks, ie the 'how-do-you-feel?' questioning of a victim or close family or friends after a tragic event. Unless a reporter has made such an approach, few would understand the reporter's angst. If unsuccessful they are then often criticised by the chief of staff or whoever for not getting 'the real story'. Every police reporter I have ever spoken to around the world finds this type of interview the most demanding. All have admitted on occasions they have avoided it by not even making the approach and later claiming the key person was not there or would not respond, ie the grass-knock.

This is on top of the regular abuse and criticism regularly experienced at a traumatic scene; being abused and sometimes physically attacked by distressed or violent people who are lashing out at the nearest irritant. All have on some occasion been sworn at, often with the added 'vulture' tag. Sometimes the story subject will attack the media people for simply doing their job, eg. when attempting to interview charged people and their friends/family outside court or people being filmed committing crimes.

In addition, the police crime reporter has to observe all the normal journalistic demands of tight deadlines, editorial policies, news room pressures, style, pictures, related-connected stories and competition with other 
news groups and reporters. The person who becomes an effective police crime reporter often works alone, has highly unusual sources and becomes almost a special breed understanding the special reporting processes to do police/crime stories. It is still regarded by many of their colleagues as the elite amongst the elite. However, many junior/cadet reporters do not see it now as the valuable training field it is.

\section{Journalists' poor image about inaccuracy}

Australian journalists along with their other world colleagues face an acute poor public relations image. This has not changed much over the past 20 years and sits along with similar low figures in the Canada, New Zealand, South Africa, the United Kingdom and the United States. One of the clear and agreed criticisms is journalists are too casual about accuracy as evidenced by many studies (see Barrett, 2006, and recent surveys) both within Australia and other western democracies. Many critics considered if journalists showed a greater concern about accuracy, this would immediately improve their status. While inaccuracy is not only the fault of the reporter, as often inaccuracies will develop through the extended news' processes, eg sub-editors in print changing pars or writing an inaccurate headline, accuracy is crucial in all reporting and especially police/crime stories. If a crime reporter gets it wrong in these stories there is little protection and trust with sources quickly becomes eroded.

Many inaccuracies will develop through poor reporting at the news gathering stage. The reporter needs to develop a healthy scepticism and understand that sources will not always know the facts or exact details. It is also obvious to every police/crime reporter that witnesses to an extreme event will frequently get very basic information wrong such as descriptions, colours, sequences, gun used, words exchanged, etc.

Why do the public react so strongly to inaccuracies and particularly in police/crime/court type stories? Because criminal and police/trauma type incidents have the most significant impact on people because these stories have the power to affect their lives, freedoms, financial status and their recovery from traumatic events. If a police reporter gets these basic facts wrong then it is much more likely to be noticed and dealt with either by the court/criminal processes or by defamation actions. Their contacts and sources soon become concerned too. 


\section{The legal position}

In July 2006, Australia achieved a remarkable milestone to at last agree on uniform defamation laws for all States and Territories. While this article does not cover this in detail, Australia is still an attractive target in which to launch a defamation action where it has some of most onerous restrictions on how the journalist can report particularly within the context of the criminal/ contempt laws. The sub judice provisions which require all parties to assume a person is innocent until proven guilty by a court of law, which most journalists would fully support, are complex. Then there are the various jurisdictions, criminal processes with various court rules, privacy restrictions, aggressive lawyers and their sometimes even more aggressive clients, police officers with egos, judges who dislike any criticism and the list is almost endless, which makes this form of reporting, with all its pitfalls, potentially horrendous; but it can be highly satisfying and at times even fun.

\section{The new found power of the police to guard communications}

In the past, the bread-and-butter first alert for potential police stories was to monitor police radio communications. Every newsroom worthy of its title had its monitors running and larger media newsrooms had a special room staffed 24-hours-a day to listen to police and related communications. Some of the listening technology was extremely sophisticated. It was not illegal to listen to police radio transmissions in Australia but it was considered risky to use them as the 'on-the-record quotes' but they were generally tolerated by all parties as a first alert. Often police would use codes for certain occurrences such as vehicle accidents, suspicious deaths, assaults, domestics etc. A clue would often be a request for a patrol officer to 'telephone communications' which immediately raised the interest of a journalist. Related radio messages were also helpful, such as the call out of the Coroner's officer, or the duty officer or special operations team etc. Even increased radio traffic back-up; 'all units...', or 'any unit within...' or 'lookout to be kept for ...' or 'officer requiring urgent assistance at...' and increased radio traffic including ambulance, fire and other support services were good hints. Sometimes it was even the call out of the media officer or a reference to other media representatives at the site which meant the reporter may have been beaten to a story! The aim of every effective police/crime reporter was to never be beaten by a rival. However there were many occasions and probably still are where rival colleagues helped each other as much as they could. It is a close fraternity. 
However, the Australian police services have now acquired digitally enhanced state of the art radio communications which has led to one of the most significant recent changes to have occurred with Australian policing and media relations. This means most journalists can no longer listen to the radio emergency channels and have to rely on the police officers to tell them when news events are occurring.

In the past many newsrooms and journalists relied heavily on monitoring the radio communication transmissions. Police communications attempted to choose multiple channels and/or talk in code to avoid having their messages understood. The police were naturally not only concerned about the media monitoring their transmissions but also the criminal elements, which it was proven they often did.

The first change a few years ago was for police officers at jobs to increasingly use mobile telephones on duty which were much harder to monitor and under the Telecommunications Act it is illegal to do so in Australia. Now the police services have such high grade communication systems, it is almost impossible to eavesdrop. It is probably now also illegal for the media to monitor their transmissions. While these new communication systems do not cover all areas, in early 2007 they were mostly only in the metropolitan regions; many rural and smaller areas still have so called 'open' systems. But not for much longer. The result is journalists cannot easily use radio transmissions as a first alert. Of course, traditionally most experienced police reporters would use other related service tipoffs and good personal contacts such as the ambulance and fire services, but even these have been harder to access and their officers 'warned off' by the police.

Following considerable criticism and concerns by Queensland media, an inquiry was held into police/media relationships resulting in a 72-page report issued in December 2004 titled 'Striking a balance: An inquiry into media access to police radio communications' issued by the Queensland Crime and Misconduct Commission and available on its website. This will be discussed later.

\section{Tom Hillston}

A former TV Channel Seven Queensland police reporter and now media liaison officer with the Queensland Police Service (QPS), Tom Hillston, said many police crime reporters were now saturated with stories and information which gave reporters little opportunity to expound their stories, question 
the party line and often appeared to be only able to cope with the bare facts and outline of a story. Because there were now fewer specialist police/crime reporters many did not understand the context of their stories and were too pressured to pursue the more difficult stories. It was now a luxury for a media organisation to have a specialist police/crime reporter.

He said while there was no intent on the part of the Media Liaison Officer or QPS to deflect a serious-fair challenge, it just did not happen often. Basically the reporter went with the set piece and did the story around the given data. It was a 'significant minority' who attempted to do any in-depth or investigative story, which he considered was superficial journalism. It appeared the reporter and/or the media newsroom had an agenda which relied on the police handouts combining the four regular roundups and any 'orange paging'. These are the alerts issued by the QPS for sudden and developing stories.

He said this now means there is a loss of immediacy in police crime reporting. His boss and head of QPS media and public affairs, Leon Bedington said he accepted the balance had shifted back towards the police but this meant '... a few more controls were back in place...' He accepted that commercial radio stations, in particular, simply read 90 per cent of the text straight from the police release and the number of media releases now issued by the police service had almost tripled. He did accept the number of skilled and experienced police/crime reporters had eroded and meant many general and junior reporters filled the gaps. This created its own individual problems because of a poor contextual understanding they often 'blundered into stories' or were following their own pre-conceived agenda.

\section{Paula Doneman}

Paula Doneman, who was at the time of the interview with The Courier Mail (Brisbane) and whohas been a police/crimereporterfor 15 years, said individual sources must be maintained and were always important. Of course, it meant the upper hand lay with the police who could choose what information to make available and when to release it. She said the police were much tighter now than they used to be.

Her father was a 'copper' and she has always had a passion for these types of stories since she was a child and believes having the passion is critical. It is always a challenge and accuracy and ethics are the most critical requirements. She must think outside the square, be open-minded, pass the various tests set by sources, have no fear of obstacles, remember the trauma 
of those often in the stories, the losses or hurt to loved ones, be factual and correct and be current:

Crime is the melting pot of everything in our society. It's traumatic and heart-breaking. Children are always difficult. The stories are enduring. You must understand clearly what is on and off-the-record (P. Doneman, interview, November 2006).

Doneman says she would only accept information if she knows the source and worries about the agendas of people who provide anonymous information, but will use it if it checks out. She is constantly developing contacts and sources and these need to be protected as they risk their jobs, families and lives by providing information.

She accepts she does have to bury some of her stories to maintain some of her contacts but argues this is rare:

I will do the tough stories even if I am going to loose my contacts, but consider they have to accept it if they are fair, balanced and accurate, then that has to be...

She would normally bypass the MLOs and go straight to the director or deputy but that may be in recognition of her status. She considers the police recruits are warned about the media and is unhappy about the young constable's attitudes. She has faced serious threats from all sides. She uses the Freedom of Information system and has found less and less material is available through it. However she asked recently to have access to files about her. She was disturbed to find there were many pages recorded by the QPS on her, but they wouldn't give her access to them. She said: 'All this must be seen in perspective...the police are not the only sources for stories...'

\section{John Flynn}

Freelance TV police/cameraman John Flynn said he was unhappy with the way police now almost abused their new found power and were reluctant to co-operate unless cornered. It was also noticeable they were keen to court the media when it suited them but some were unwilling if it was a negative story. He considered the media was hampered in its role as a watch-dog for society and fourth estate role. He said the situation was returning to the bad 
old days of the pre-Fitzgerald era in Queensland. He criticised some of his media colleagues for obviously showing bias in 'protecting' their sources by not running critical stories and considered some media organisations had two types of police crime reporters - the good guys and the bad guys, ie the good guy would not go with the negative police type story. He said police crime required the most finely developed sense of ethics and often many junior reporters were '...not up to it...' .

The new technology had made it difficult and even the use of codes by police communications for various incidents needed to be deciphered. He used a range of contacts to confirm stories; traditionally the ambulance, fire and other emergency services were obvious sources. There were subtle clues which required experience to detect such as increased radio traffic, a request for an investigating officer to telephone, the call-out of particular squads or supervisors. He used the police union and sometimes obtained stories by simply having members of the public telephone when they heard sirens. There are many citizens who telephoned such as taxi drivers, tow truck operators, undertakers. The list is almost endless.

\section{Tony Fabris}

Brisbane Channel Nine police/crime reporter Tony Fabris is openly critical of police media as sources for stories because he considers they are a 'place of last resort'. If he approached them about a story, particularly his own 'exclusive', he ran a real risk the story would somehow leak to other news outlets. He considers too many young junior reporters are simply 'spoon fed' stories of convenience by police media.

He says it has taken him 'a very long time' to develop his own sources and gain the trust of police officers who will provide him with the information and tip-offs he needs to do his job well. He understands police media may need to provide other outlets with material for the big stories but considers for him it too risky most of the time. He said he has sometimes given the negative tough story to a colleague to remain 'untainted' himself. He had 'buried' a story and not done it preferring to avoid losing the support of his contacts. Paula Doneman, however, said she would still pursue the tough story and force the police to recognise this was her role, and providing she was fair and accurate, believed this was reasonable. She said she had lost some 'sources' by adopting this practice.

It is the author's view and was his practice that there were occasions in 
which he gave the hugely negative story to a colleague to avoid being 'tainted'. However if the tough story had to be done then he preferred to do it well and accurately to avoid it being criticised for a lack of factual/contextual depth. He too had lost some contacts but the underlying basic law of effective police/ crime reporting was to be fair and accurate and if that can be maintained then the reporter would survive. The honest-broker reputation cannot be broken.

\title{
Steve Marshall
}

Steve Marshall is a former police officer and detective and now long term police reporter with Channel Nine (formerly with other networks). He is currently bureau chief for Channel Nine in Townsville. He said:

\begin{abstract}
There are very few effective police/crime reporters. They are a threatened species and of all the rounds, it is the most difficult. There are some absolutes; to be accurate, immediate, know the background, don't burn your sources and not become too cosy particularly with the police and union (S. Marshall, interview, November 2006).
\end{abstract}

Doing the round well required 'honesty and accuracy' and that was why many journalists did not survive doing the round for long or found it just too difficult or even traumatic. He said many junior reporters saw the glamour of the round but didn't seem to have the 'heart or stamina for it'. They did not seem to want to do more than the superficial story and found it too difficult or were unwilling to chase the harder angles. They found it difficult tounderstand the policehierarchical systemand processes. Few seemed to understand the police officer's perspective or understand that the police officer had more to fear from their superiors/supervisors, or risking the positive outcome of investigations and the courts than the media.

It is the author's view police officers more than any are all too aware of being judged as promoting a 'trial by the media' during investigations. The reality is too, as any court reporter will have witnessed, police officers are regularly grilled by defence counsels about what they said to the press or what they said in statements issued at press conferences. Unless a person has been in the witness hot seat in a senior court, the pressure can be very unpleasant. For a police officer, a 'stuff up' in court could cause a trial to be lost or aborted.

Marshall considered the relationship between the police/crime reporter and the police services had slipped back now to almost the point it was at the 
pre-Fitzgerald days in Queensland where many stories were not done well or not at all. He acknowledged that to 'break the big corruption stories' may require an outside reporter.

He was scathing of the police MLOs and described the QPS media unit as the office of 'disinformation'. He tried to do his own thing and regarded the union as a legitimate alternative source as it could often speak when the operational police officer could not. He was wary of anonymous and or aggrieved sources and always asked himself: 'Why are they telling me this?'

It is the author's view that this tightening of relationships and release of information by the police services encourages leaks and/or disgruntled officers to go more frequently to the media. This can lead to greater inaccuracies of stories. It also allows the police critics more oxygen if not promptly dealt with honestly by the police services.

\section{Leon Bedington}

The head of QPS media at the time of the interview, but not now, Leon Bedington, said some of the more experienced reporters did 'sanitise' their reports to protect their sources and did have their 'sacred cows'. He said following the Crime and Misconduct Commission report issued in December 2004, the media had been challenged to provide any examples of important stories missed because of the new digitilisation of police communications. They did not give any. There were examples and complaints by the media of them particularly not obtaining best footage or photos. He said there was nothing to stop reporters doing more in-depth stories which did not rely on radio transmissions, but there appeared to be a disinclination by reporters to undertake them (suggesting a laziness on the part of reporters and/or the lack of resources and time now available to current reporters). He suspected this was because of a lack of media management support for such stories and the growth of opinion pieces. He also bemoaned the fact that most reporters were not specialist-rounds-reporters and reporters expected the stories to be laid on for them, ie were spoon fed. Many reporters appeared not to stay in the reporting role for very long. He said the QPS had increased its numbers of media releases (or reports of incidents) from 80 a month three years ago to now more than 300 per month on average.

He was concerned with the number of young reporters who appeared 
to have a set agenda, either determined by them or their supervisors and were not prepared to consider alternative viewpoints. He said on occasions, stories, sometimes speculative, were run without any request for any official comment. Too many stories were now being run which he would describe as 'opinionated analysis'.

Naturally he was concerned with anonymous or 'leaked' sources because police officers doing so were breaching their own regulations and sometimes even breaking the law. He said the inexperienced reporters with the set-agendas were more difficult to deal with because it made the work of police media officers harder. He said: 'There are not many people who can do the police/crime round well and those that can have largely moved on. Newsrooms need to give it greater attention and they'd probably get a better story and better results.'

\section{Alan Knight}

Professor Alan Knight, head of journalism at the Queensland University of Technology, says the old style police/crime reporter is seen by many media managers as too expensive and risky. He says: 'It's not a game for young players...'. To do the round or job well means negotiating through, now, a brigade of PR officials. Also many media organisations cannot employ specialist reporters in many fields such as industrial or local government etc. Concentration of media ownerships with fewer players and less diversity combined with cost cutting has meant less experienced journalists being asked to do more with less time and resources. The growth of the PR industry had forced many police/crime reporters to rely too heavily on spin and or anonymous sources.

Knight says there has been shift in news coverage from factually based stories to much more personality and opinion stories. He says TV, with its short 120 second picture-based stories, does not lend itself well to the more investigative stories. It is difficult to cover police/crime type stories well on TV.

He agreed accuracy was paramount in doing any round well but particularly the police/crime round as any breaches immediately open the media organisation to legal action. It's an expensive form of reporting and requires a great deal of trust by the chief of staff or organisation to allow a police/crime reporter free reign to develop well researched and investigative stories. It can often rely on anonymous sources which have their own inherent difficulties not the least, if challenged, may mean they cannot be revealed. The 
journalist may need to be prepared to be jailed to avoid their sources identification as there are no real shield laws in Australia as there are for lawyer/client priest/parishioner relationships. It does open the possibility too of a dishonest journalist having no source at all.

Knight says the role of reporting has changed because of the shift away from hard news, the rise of the PR official, the decline in the number of specialist rounds, the increasing use of telephone and unwillingness for the organisation and/or reporter to get out and walk their rounds. The move away from police/crime reporting to the safer and easier role of doing the story at the court reporting phase was simply because it is regarded by the media as too expensive and risky. It did lose its currency though.

\section{Different objectives}

It is the author's view that there is a constant problem which remains between what the police service and the media consider newsworthy. Often a police officer will not 'see' the news value in a story whereas a journalist, particularly one with a 'nose' for news, will see it. A police officer may see the incident as a simple routine police matter. Naturally this gets down to what each is trained to do, ie a police officer to do police work and a journalist to find and develop stories. It has often been observed the police officer and reporter are chasing much the same information; the who, what, where, when, why and how, but the difference is what's done with the answers. Ultimately the police officer is responsible to the commissioner; the reporter to their news editor and public.

\section{'You stay out of trouble if you don't talk to the media'}

Also there has long been a culture of many police officers who consider the safest path is to say nothing to the media '.... and then you don't get any grief' with all the restrictions and privacy concerns. Their view is it is best to stay out of trouble by staying away from the media because then you do not get into any difficulty with the police hierarchy. Naturally some media publicity can inhibit investigations. However, there are also many investigations which, without media support, would have little chance of success, particularly in seeking the public's information. Also the vast majority have little direct contact with police officers in their daily lives with one major negative exception; traffic police and particularly their issuing of infringements. Therefore the public's perception of the police services depends 
heavily on its media portrayal. The Police Services should be reminded of this regularly. This is a reason for police services to always remember most people will only experience dealing with police officers on traffic matters where often they tend to be the least well trained in dealing amicably with the public. Keeping the media on-side through the media is vital as most internal police assessments demonstrate. So it has to be more balanced.

Some of the police reporters were critical of the training practices of the QPS where they suspected cadet police officers were taught to distrust the media and avoid contact with them. It is obvious a junior constable just graduated will be very hesitant to engage with the media, but many police careers and investigations have been enhanced by a wise and appropriate relationship with the media. Some investigations would never have been resolved without the media engagement and support. The smarter police officers know this and accept it must be a two-way deal.

It is and always will be a delicate, fine balance resting on trust and following sound practices based on mutual integrity. It would appear the balance has shifted significantly in favour of the police because they have the upper hand and they use it. The media has become lazy, too rushed and all too willing to cut costs and let inexperienced reporters cover this important round.

It also raises the real concern this author has about the balance between the PR officials (the spin doctors) and the journalists which is out of balance. Journalism educators need to educate and forewarn their students about this relationship which can and should be ethical but often deteriorates when new reporters are chasing stories. The author taught in a university business school in public relations at a large university for 18 months. He was somewhat overwhelmed to find much of the course and unit contents were about getting the media to promote 'your client's message', ie. how to write media releases, run media campaigns, media kits, media strategies, gimmicks, freebies, brochures, networks, web-sites and so on. The PR students are well-prepared to meet the journalists as any examination of their curriculum will show. Few if any Australian journalism schools prepare their students for the encounter.

If the police/crime stories are not done well and thoroughly, as Steve Marshall and John Flynn suggest, the balance could shift back to the coverups, corruption and inefficiencies which characterised the pre-Fitzgerald era in Queensland. Then the Fourth Estate - the media - ceases to serve one of its most critical roles; that of being a watchdog and check in a modern democracy. 


\section{A news spy in every suburb}

It was the author's experience that every suburb and almost every shopping centre has a willing informant who is often very media-sensitive and savvy - the local newsagent. This was used without fail and often they had the exact details of where the house, school, shop or incident was and often who the local people were. More importantly they knew the value of selling more newspapers: a big advantage for a print journo. And there is always the next door neighbour or shop or similar trader. There is still nothing quite so helpful as the white or yellow pages telephone directories. Many newsrooms had access to a reverse telephone directory by street address too.

\section{Conclusion}

How this specialist role of police reporting is performed does affect how we teach and what we teach. Most importantly it again raises the need for all journalists to raise the standard and reverse the negative perception of journalists by the public. An improvement in and greater emphasis on accuracy would be an ideal start and that begins first at journalism schools. It re-emphasises the need for reporters to get the facts accurately, walk the streets and eye-ball sources. It is too easy to sit behind a computer and trawl through websites, occasionally use the telephone and do interviews. Police/crime reporting is very much a face-to-face role and reporters must use sources who they know and trust. They must accept the reporter is accurate, ethical and will not stuff-up the story. These are the qualifications for any effective reporter as journalism is very public in its results. As the saying goes: 'Doctors bury their mistakes, lawyers have theirs go to jail, but journalists' mistakes are there for all to see.'

\section{Interviews}

Bedington, L. (2006). Director, Police Media and Public Relations, Queensland Police Service, at the time of the interview. Personal interview, November.

Clack, P. (2006). Freelance journalist and former police/crime reporter with The Canberra Times. Personal interview, November.

Doneman, P. (2006), The Courier Mail at the time of the interview, but has since left the newspaper. Personal interview, November.

Fabris, T. (2006). Channel Nine police/crime reporter, Brisbane. Personal interview, November.

Flynn, J. (2006). Freelance TV reporter and camera operator. Personal interview, November. 


\section{JOURNALISM DOWNUNDER}

Hillston, T. (2006). Police media liaison officer, QPS and former Channel Seven police/crime reporter (Brisbane). Personal interview November.

Knight, A. (2006). Professor, head of journalism discipline, Queensland University of Technology. Personal interview, November.

Marshall, S. (2006). Channel Nine reporter (Townsville) and former QPS police officer. Personal interview, November.

\section{References}

Barrett, Rosanne. (2006). Worse than used car salesmen? A survey into why journalists are distrusted and what can be done about it. Unpublished paper prepared for a QUT project in October.

Clack, P. (1996). Report on Churchill fellowship of police and media practices. Unpublished.

Striking a balance. An inquiry into media access to police radio communications. Crime and Misconduct Commission (2004). Queensland, December.

Philip Castle is currently a journalism lecturer at the Queensland University of Technology. He has more than 30 years' experience in the media-he served in Vietnam from 1969 to 1971, was a print police crime reporter and became Director of the Australian Federal Police's Public Affairs Office for nine years. He has been a public relations lecturer and has now been a journalism lecturer for almost 10 years. An earlier version of this article was presented as a paper at the Second Joint Journalism Education (JEA)/Journalism Education Association of New Zealand (JEANZ) conference, Auckland, December 4-7. p.castle@qut.edu.au 